\title{
Performance and Optimization of a Small Hybrid Solar-Thermal Collector
}

\author{
Amy Lebar, Heather E. Dillon \\ Department of Mechanical Engineering, University of Portland, Portland, USA \\ Email: dillon@up.edu
}

How to cite this paper: Lebar, A. and Dillon, H.E. (2018) Performance and Optimization of a Small Hybrid Solar-Thermal Collector. Smart Grid and Renewable Energy, 9, 259-271.

https://doi.org/10.4236/sgre.2018.912016

Received: November 5, 2018

Accepted: December 25, 2018

Published: December 28, 2018

Copyright ( 2018 by authors and Scientific Research Publishing Inc. This work is licensed under the Creative Commons Attribution International License (CC BY 4.0).

http://creativecommons.org/licenses/by/4.0/

(c) (i) Open Access

\begin{abstract}
A hybrid solar collector was designed to investigate the effects of combining two different solar collector techniques on the overall collector's effectiveness. While most solar collectors focus only on one solar collection method, the small hybrid system uses a flat plate collector in conjunction with five evacuated tubes to absorb the most energy possible from both direct and diffuse solar radiation. Data was collected over four months while the system operated at different flow rates and with various levels of available insolation from the sun to evaluate the performance of the solar collector. To understand the relative contribution of the flat plate collector and the evacuated tubes, temperature differences across each part of the system were measured. The results indicate the average first law efficiency of the hybrid system is $43.3 \%$, significantly higher than the performance of the flat plate alone. An exergy analysis was performed for this system to assess the performance of the flat plate system by itself. Results of the second law analysis were comparable to the exergetic efficiencies of other experimental collectors, around 4\%. Though the efficiencies were in the expected range, they reveal that further improvements to the system are possible.
\end{abstract}

\section{Keywords}

Solar Thermal Energy, Flat Plate Collector, Evacuate Tube Collector, Exergy, Second Law of Thermodynamics

\section{Introduction}

Renewable energy is an important alternative to conventional burning of fossil fuels and natural gases. The current supply of fossil fuels has been accumulating for millions of years and is deemed a finite resource because the supply is being consumed more rapidly than it can be replenished. 
Solar energy is one example of a renewable energy source. There are two main methods for converting solar energy into more useful forms of energy like electricity or heat: 1) photo-voltaic cells, and 2) solar thermal systems. Photo-voltaic cells are widely used and have been heavily investigated. Solar thermal systems are less common and have not been investigated with the same detail as photo-voltaic systems. Within the field of solar thermal systems, there are two primary constructions: 1) flat plate collectors (FPC), and 2) evacuated tube collectors (ETC), and each has its own strength. Flat plate collectors can collect both direct and diffuse radiation, and also operate better at low temperatures. Although ETC systems are also able to absorb both direct and diffuse radiation, they are often designed to be more efficient at collecting direct sunlight. Evacuated tubes also are advantageous in higher absorber temperatures than FPC systems [1]. Flat plate collectors typically have efficiencies near $45 \%$, while ETC systems can achieve efficiencies over $60 \%$ [2].

In an effort to optimize the efficiency of both systems in a rainy climate, this project combined the two designs into one small hybrid prototype collector utilizing both ETC and FPC systems. Hybrid systems have not been studied in detail in the size or climate that this paper describes. No small hybrid collector system of this type has been analyzed with the second law of thermodynamics.

\section{Background}

Evacuated tube solar collectors are composed of the evacuated tubes themselves, a heat pipe, and a manifold. When placed in sunlight, the tubes absorb solar energy and convert it to heat while utilizing the vacuum-sealed area between the two glass layers as an insulator to prevent heat loss. The copper heat pipe within the tubes manifests into a copper bulb at the top of the tubes. Within the heat pipes a liquid is evaporated and condensed using heat from the sun. As the liquid evaporates, it rises through the heat pipe where it transfers its heat to the ETC working fluid passing over the bulbs and falls to the base of the heat pipe as it condenses. In the hybrid system, this heat transfer takes place in the manifold, an insulated box containing the bulbs at the top of the heat pipes, and with the working fluid of the system passing over the bulbs [3].

Flat plate collectors are composed of fluid-filled copper pipes running across a metal flat plate. FPC systems use direct conduction to transfer solar energy to the working fluid in low-temperature conditions. In the hybrid solar system, the plate is enclosed in an aluminum box, and sealed with a transparent cover as shown in Figure 1. Insulation lines the inside of the box to maximize the amount of heat transferred to the fluid running through the pipes. On their own, FPC systems are primarily used for domestic hot-water heating, space heating, or industrial systems as a supply for a pre-heat before a larger collector [3].

Table 1 provides a summary of work that has been done with FPC and ETC systems. When known, the surface area $\left(A_{s}\right)$ of the system and key features are reported. 


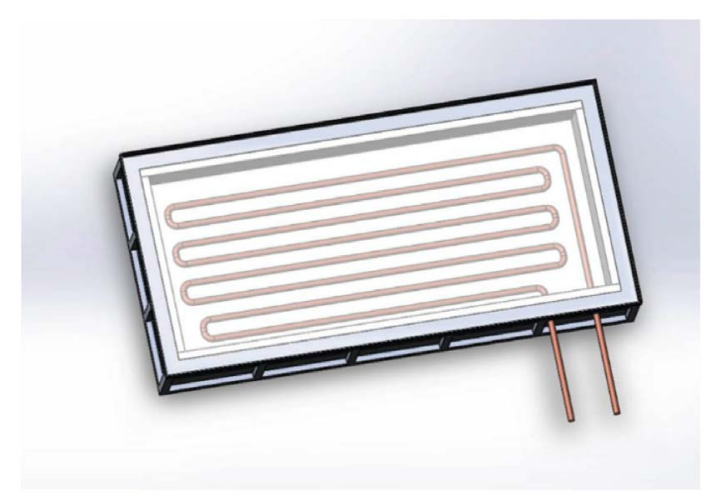

Figure 1. Computer-generated model of flat plate collector designed for the hybrid collector.

Table 1. Summary of recent experimental work with flat plate collectors (FPC) and evacuated tube collectors (ETC).

\begin{tabular}{|c|c|c|c|c|c|}
\hline Citation & Year & Type & System & Dimensions & Location \\
\hline Ayompe et al. [3] & 2011 & FPC & $\begin{array}{l}\text { Forced circulation; } \\
300 \text { L water tank }\end{array}$ & $\begin{array}{c}A_{S}=4 \mathrm{~m}^{2} 12 \\
\mathrm{~mm} \text { copper } \\
\text { pipe }\end{array}$ & Dublin, Ireland \\
\hline Ayompe et al. [3] & 2011 & ETC & $\begin{array}{l}\text { Forced circulation; } \\
300 \text { L water tank }\end{array}$ & $\begin{array}{l}A_{S}=3 \mathrm{~m}^{2} \\
30 \text { tubes }\end{array}$ & Dublin, Ireland \\
\hline Chaichana et al. [4] & 2010 & FPC & $\begin{array}{l}\text { Comparison to } \\
\text { solar-boosted heat pump; } \\
300 \mathrm{~L} \text { water tank }\end{array}$ & $A_{S}=2 \mathrm{~m}^{2}$ & $\begin{array}{l}\text { Lampang, } \\
\text { Thailand }\end{array}$ \\
\hline Gang et al. [5] & 2011 & FPC & $\begin{array}{c}\text { FPC as first stage of water } \\
\text { heating process; R123 } \\
\text { working fluid. }\end{array}$ & $A_{S}=2 \mathrm{~m}^{2}$ & $\begin{array}{l}\text { Hefei City, } \\
\text { China }\end{array}$ \\
\hline Yang et al. [6] & 2015 & ETC & $\begin{array}{c}\text { Novel manifold header } \\
\text { used to improve } \Delta T\end{array}$ & $A_{S}=4.97 \mathrm{~m}^{2}$ & $\begin{array}{l}\text { Nanchang, } \\
\text { Jiangxi }\end{array}$ \\
\hline Manek et al. [7] & 2016 & ETC & $\begin{array}{l}\text { Booster mirrors used } \\
\quad \text { to improve } \Delta T\end{array}$ & 1.5 m Length & \\
\hline Present Work & 2018 & $\begin{array}{l}\text { FPC and } \\
\text { ETC }\end{array}$ & $\begin{array}{l}\text { Hybrid system; Forced } \\
\text { circulation }\end{array}$ & $A_{S}=1.16 \mathrm{~m}^{2}$ & $\begin{array}{l}\text { Portland, } \\
\text { Oregon }\end{array}$ \\
\hline
\end{tabular}

The work of Ayompe et al. involves both FPC and ETC systems. The paper compares the performance of the two systems in identical conditions, finding that the ETC system generate about $0.3 \mathrm{kWh}$ more per day than the FPC [3]. Gang et al. utilized an FPC as a means for pre-heating the working fluid (in this case R123) before the fluid was further heated by a compound parabolic concentrator. The heat from this combined system was transferred to an Organic Rankine Cycle (ORC) to generate electricity [5]. The work of Manek et al. succeeded in increasing the outlet temperature of the water in the ETC system from $70^{\circ} \mathrm{C}$ to $100^{\circ} \mathrm{C}$ with the addition of booster mirrors [7].

Table 2 provides a summary of exergy analyses conducted with experimental FPCs. The second law (exergetic efficiency) is representative of how energy resources in a system are used. The second law efficiency is often lower than first 
Table 2. Summary of experimental exergy analysis on flat plate collectors.

\begin{tabular}{cccccc}
\hline Citation & Year & Fluid & $\begin{array}{c}\text { Flow Rate } \\
{[\mathrm{kg} / \mathrm{s}]}\end{array}$ & $\begin{array}{c}\text { Insolation } \\
{\left[\mathrm{W} / \mathrm{m}^{2}\right]}\end{array}$ & $\begin{array}{c}\text { Exergy } \\
{[\%]}\end{array}$ \\
\hline Jafarkazemi [10] & 2013 & Water & $0.03-0.05$ & $204-968$ & $2-8$ \\
Ge et al. [11] & 2014 & Water & 0.05 & 800 & 5.96 \\
Said et al. [8] & 2015 & Nano-Fluid & 0.033 & $\max 1400$ & $\approx 25$ \\
& & Water & 0.06 & avg 592 & 4.53 \\
Kalogirou et al. [9] & 2015 & $\mathrm{CO}_{2}$ & 0.06 & avg 592 & 3.41 \\
Present Work & \multirow{2}{*}{2018} & Water & 0.005 & avg 1061 & 4.33 \\
\hline
\end{tabular}

law efficiency for a system because it captures the idea of best case energy and resource utilization.

The highest second law efficiency came from a study done by Said et al., 25\%. This collector was used to study the effects of adding graphene nanoparticles to water and acetone on the performance of the collector [8]. The other study that experimented with an alternative working fluid to water was conducted by Kalogirou, et al. Carbon dioxide was compared to water as the working fluid in a FPC. The study found that carbon dioxide produced a lower exergy efficiency than water under the same conditions by approximately $1 \%$. The exergetic efficiency of water averaged $4.53 \%$ [9]. All collectors, excluding the two mentioned above, used water as the working fluid, which is also the working fluid in the collector being analyzed in this study. A study by Jafarkazemi and Ahmadifard aimed to identify the optimal flow rate for the working fluid in collector and found that flow rates near $0.3 \mathrm{~kg} / \mathrm{s}$ resulted in close to $8 \%$ exergetic efficiency [10]. Ge et al. also conducted a study on a flat plate, finding an exergetic efficiency of $5.96 \%$ with a flow rate of $0.05 \mathrm{~kg} / \mathrm{s}$ and an average insolation of 800 $\mathrm{W} / \mathrm{m}^{2}[11]$.

In 2014, Hamed, et al. completed a theoretical study of a flat plate collector. The model showed a $60 \%$ second law efficiency [12]. This theoretical model proved to be much more efficient according to the second law of thermodynamics compared to experimental collectors, which averaged a $5 \%$ efficiency.

\section{Hybrid-Solar Collector Design}

In the summer of 2015, the hybrid solar system was redesigned, from a prior version documented by Zielinksi [13] [14]. Multiple changes were implemented in the modified system. The most significant of these changes was a new flat plate design. In the previous design, the flat plate was enclosed in a box made of wood at a fixed tilt angle and orientation relative to the sun. Within the wooden enclosure, the water would pass through copper piping until it reached the manifold before leaving the system. The manifold housed the copper bulbs of five evacuated tubes. The bulbs were arranged linearly and parallel to the flow of water.

The new design of the collector separated the flat plate and manifold as shown in Figure 2. The flat plate collector reused the same copper pipe, but changed 


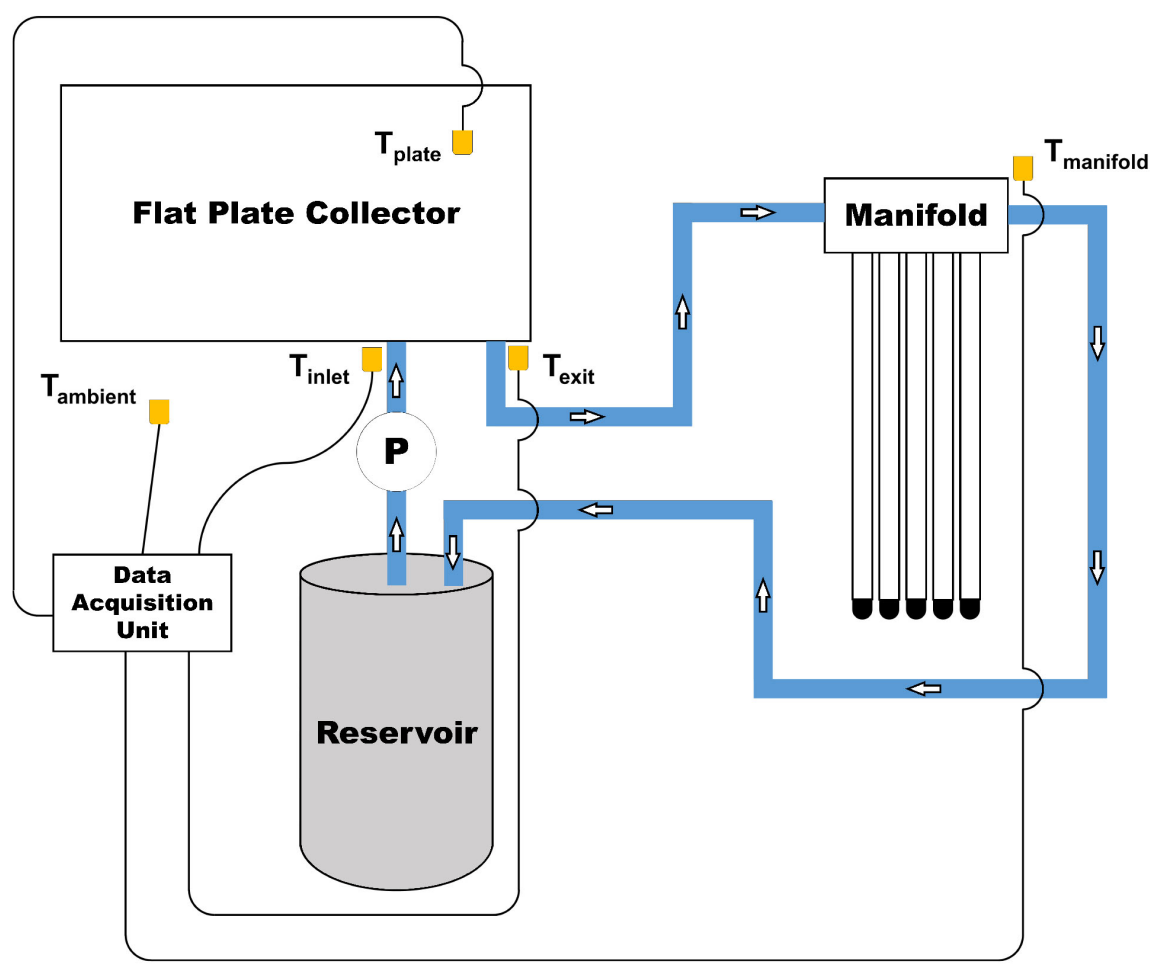

Figure 2. Overall configuration of the hybrid collector system. Testing setup indicating flow direction and location of thermocouples. Thermocouples are shown as small squares and the pump to circulate the liquid water is shown as a circle with a $\mathrm{P}$.

the location of the inlet and exit-they were positioned at the bottom of the collector to reduce the stress on the hose attachments. A new stand was built for the flat plate with bearings and wheels that enabled the tilt and orientation of the plate to be altered. From the exit of the flat plate, the water flowed through a hose to the newly designed manifold shown in Figure 3. The flow in the manifold slows considerably due to the manifolds larger cross-sectional area, and the bulbs of the evacuated tubes were staggered within the manifold to maximize the bulb surface area contacted by the water. A second valve was also added after the manifold to better control the flow in the separated system.

Additional changes to the system include its location, and placement of the evacuated tubes. The system was moved to a more central location on the roof in an effort to increase sun exposure. The new manifold, housing the bulbs of five evacuated tubes, was constructed and connected to the exit of the flat plate with high temperature hose. The evacuated tubes were placed on the metal stand at an angle of about 10 degrees.

\section{Methods}

The testing setup is shown in Figure 2. The hybrid solar collector was tested by first filling the reservoir with water, and the pump was plugged in. Water flowed through the copper piping on the flat plate before entering the manifold and returning to the reservoir. By adjusting each of the two ball valves, the flow was set 

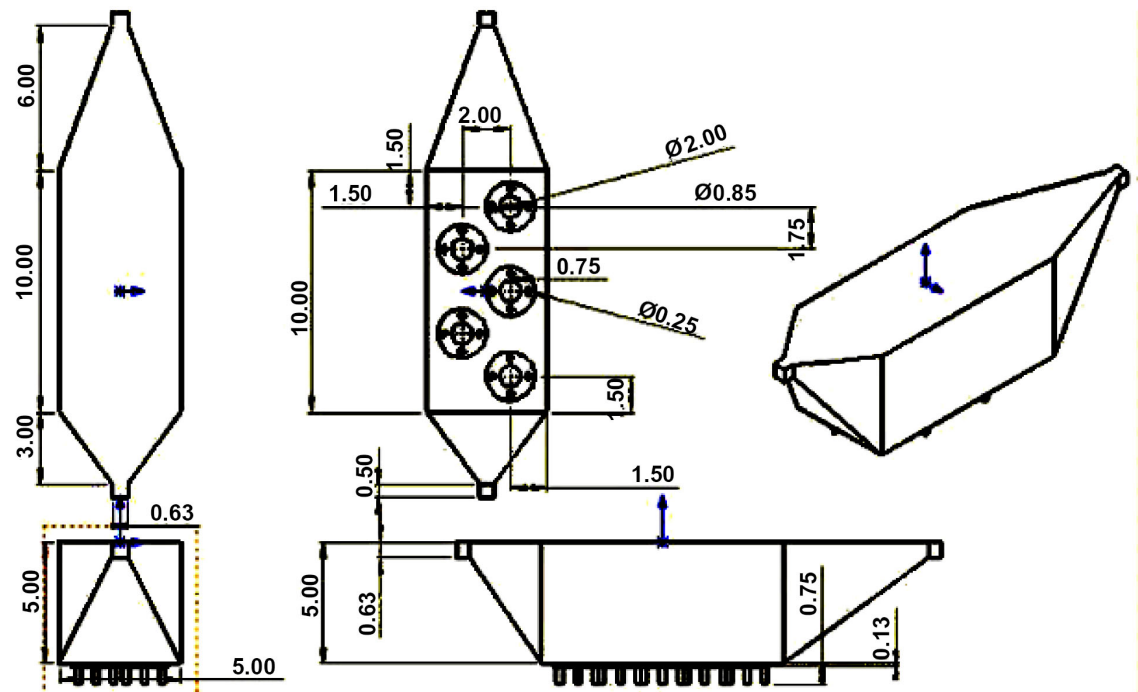

Figure 3. Solidworks drawing of the new manifold by A. Zielinski.

to a constant rate around 0.006 liters/second. Thermocouples located at the inlet and exit of the plate, after the manifold, and on the plate, as well as an insolation meter were hooked to an Arduino board for data acquisition. An Arduino script with CoolTerm software was used to collect the temperature and insolation data into a single text file. The file was imported into a Matlab code which plotted the temperature and insolation data in a single figure. Information such as the maximum temperature differences across each component of the collector, and percent contribution of each component to the total temperature change were also found and recorded.

The heat transferred to the system ( $\dot{Q}_{\text {absorbed }}$ ) was found using a simplified form of the first law of thermodynamics, where $\dot{m}$ is the mass flow rate and $\Delta h$ is the change in enthalpy in the system.

$$
\dot{Q}_{\text {absorbed }}=\dot{m} \Delta h
$$

The enthalpy calculation can be simplified using the temperature difference from the inlet to the exit of the collector and the relatively constant specific heat of water, resulting in a further simplified form of conservation of energy.

$$
\dot{Q}_{\text {absorbed }}=\dot{m} C_{p} \Delta T
$$

$C_{p}$ is the specific heat of water in the collector, and $\Delta T$ is the change in temperature from the inlet to exit of the system. For the system model the mass flow rate was assume to be constant, with an average value of $\dot{m}=0.1 \mathrm{~kg} / \mathrm{s}$.

The total energy available for the collector to absorb $\left(\dot{Q}_{\text {available }}\right)$ is determined from the amount of insolation into the system. No assumptions about transmission efficiency or radiation were included in the model.

$$
\dot{Q}_{\text {available }}=I \cdot A_{s}
$$

$A_{\mathrm{s}}$ is the surface areas of the flat plate and evacuated tube sections, and $I$ is the insolation value measured in $\left[\mathrm{W} / \mathrm{m}^{2}\right]$. The first law efficiency $(\eta)$ was 
calculated with the heat into the system divided by the total energy available.

$$
\eta=\frac{\dot{Q}_{\text {absorbed }}}{\dot{Q}_{\text {available }}}
$$

The second law efficiency of the collector is derived from the exergy balance as follows [15]. The second law (exergetic efficiency) is representative of how energy resources in a system are used.

$$
\varepsilon=\frac{\text { exergy }_{\text {out }}}{\text { exergy }_{\text {in }}}=\frac{\dot{E}_{f, \text { out }}-\dot{E}_{f, \text { in }}}{\dot{E}_{q, \text { in }}}
$$

The exergy out is represented by the exergy leaving the system. This is calculated using the difference in the flow exergy between the inlet $\left(\dot{E}_{f, \text { in }}\right)$ and outlet $\left(\dot{E}_{f, \text { out }}\right.$ ) of the system. The flow exergy calculation is detailed by Moran [15].

$$
\dot{E}_{f}=\dot{m}\left[\left(h-T_{o} \cdot s\right)_{\text {in }}-\left(h-T_{o} \cdot s\right)_{\text {out }}\right]
$$

$\dot{m}$ is the mass flow-rate of the working fluid (in this case, water) through the system, $h$ is the enthalpy of the water at the inlet and exit of the collector, $T$ is the dead state temperature assumed to be $25^{\circ} \mathrm{C}$, and $s$ is the entropy of the inlet and exit water. The exergy in to the system is given by the exergy available to the system provided by solar radiation.

$$
\dot{E}_{q, i n}=\left(1-\frac{T_{o}}{T_{s}}\right) \dot{Q}_{\text {available }}
$$

For this calculation $T_{s}$ is the apparent solar temperature as exergy source, assumed to be $4350 \mathrm{~K}$ based on the literature [11].

\section{Results}

\subsection{Experimental Results}

The temperature and insolation data collected each day was graphed and analyzed to assess the performance of the modified hybrid collector. Figure 4 shows an example of the recorded thermocouple and insolation sensor data for one day (August 25, 2016). This day was chosen as a representative sample of a typical data collection day. As time increased in the figure, the temperature change across the collector increased as well. A maximum change in temperature of $16.5^{\circ} \mathrm{C}$ was achieved at a constant flow rate of $0.32 \mathrm{~kg} / \mathrm{s}$. The system was operated at the lowest flow rate possible ( $\sim 0.005$ liters $/ \mathrm{s})$ in order for the most heat to be transferred to the water. The flat plate was oriented due south at a fixed tilt angle of $30^{\circ} \mathrm{C}$ from horizontal, and the manifold was insulated. The system was operated for over 8 hours during the peak sunlight hours available, and the highest insolation was $1000 \mathrm{~W} / \mathrm{m}^{2}$.

The maximum efficiency of the collector on August 25 was $26.6 \%$, and a maximum temperature increase of $16.5^{\circ} \mathrm{C}$. Several efficiencies calculated from small time resolution data were higher, but were not considered reasonable due to faulty thermocouple readings caused by the high sample frequency (1 sample 

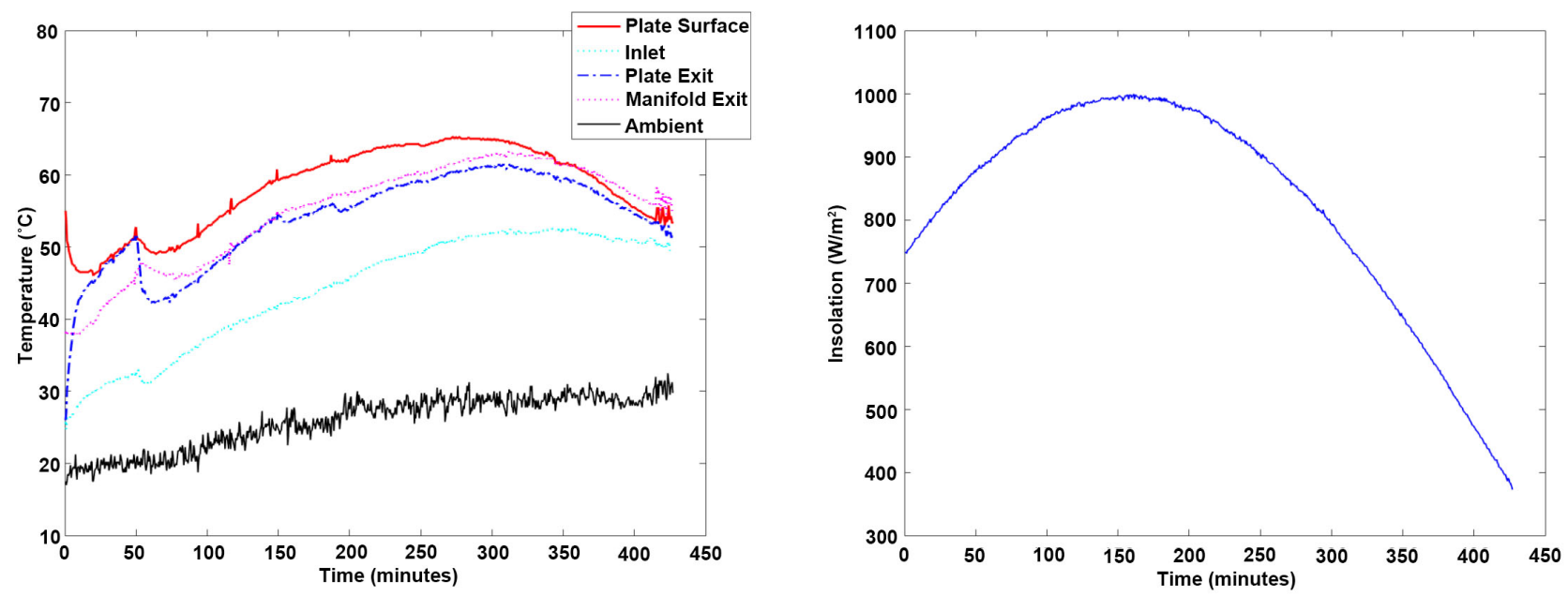

Figure 4. Example of the total system temperature difference and insolation data collected throughout the day of August $25,2016$.

every 30 seconds). A summary of the other experimental tests performed is shown in Table 3.

One key upgrade performed during testing was to add insulation to the evacuated tube manifold to increase the temperature change. Table 4 displays the effect of an insulated manifold on the performance of the collector. Prior to being insulated, the evacuated tube manifold contributed $52.5 \%$ of the total temperature increase in the system with an average maximum insolation across all of the test days of $1070 \mathrm{~W} / \mathrm{m}^{2}$. After insulation was added, the manifold contributed $64.5 \%$ of the total temperature change with an average maximum insolation of $1050 \mathrm{~W} / \mathrm{m}^{2}$. Improvements to the insulation could further increase the effectiveness of the manifold.

\subsection{First and Second Law Analysis}

Table 5 provides an overview of the results of the first and second law analysis for the system. The flat plate collector had an average second law efficiency of $4.33 \%$. This was much lower than the first law efficiency, which was on average $43 \%$. The effect of insolation on the efficiency does not follow a clear trend. Figure 5 show how the second law efficiency varies with temperature change. An increase in the temperature difference between the inlet and exit of the system shows an increase in the second law efficiency. This makes sense because the strong relationship between the second law of thermodynamics and temperature is well established as shown in Equations (6) and (7).

\section{Discussion}

This design iteration was expected to have a higher efficiency and better performance than the previous design documented by Zielinski et al. [13]. Results show, however, that the previous collector had a slightly higher overall efficiency (45\%) than the current system (43\%). Because this was the first summer of data collection, the system was being optimized over the course of the four months of 
Table 3. Summary of experimental data collected.

\begin{tabular}{cccccc}
\hline Test & $\begin{array}{c}\text { Angle from } \\
\text { Horizontal }\end{array}$ & Orientation & $\begin{array}{c}\text { Maximum } \\
\text { Insolation } \\
{\left[\mathrm{W} / \mathrm{m}^{2}\right]}\end{array}$ & $\begin{array}{c}\text { Maximum } \\
\text { ETC } \Delta T \\
{\left[{ }^{\circ} \mathrm{C}\right]}\end{array}$ & $\begin{array}{c}\text { Maximum } \\
\text { FPC } \Delta T \\
{\left[{ }^{\circ} \mathrm{C}\right]}\end{array}$ \\
\hline 1 & $35^{\circ}$ & SW & 1155 & 18.8 & 11.3 \\
2 & $30^{\circ}$ & SW & 1008 & 13.3 & 7.25 \\
3 & $30^{\circ}$ & SW & 1031 & 6.00 & 10.3 \\
4 & $26^{\circ}$ & SW & 838.2 & 5.25 & 14.0 \\
5 & $35^{\circ}$ & SW & 1248 & 5.00 & 7.25 \\
6 & $35^{\circ}$ & SW & 1022 & 20.3 & 2.75 \\
7 & $30^{\circ}$ & SW & 1246 & 9.25 & 8.75 \\
8 & $32^{\circ}$ & SW & 1018 & 9.25 & 9.75 \\
9 & $26^{\circ}$ & SW & 1007 & 12.8 & 2.50 \\
10 & $30^{\circ}$ & SW & 1000 & 12.3 & 4.25 \\
11 & $26^{\circ}$ & SW & 1029 & 7.00 & 9.00 \\
12 & $35^{\circ}$ & SW & 1002 & 8.00 & 10.3 \\
13 & $30^{\circ}$ & S & 1248 & 5.50 & 4.00 \\
14 & $27^{\circ}$ & S & 1002 & 16.5 & 3.25 \\
Average & & & 1061 & 10.7 & 7.48 \\
\hline
\end{tabular}

Table 4. Summary of impact of insulation to the evacuated tube manifold.

\begin{tabular}{cccc}
\hline & Units & Without Insulation & Insulated \\
\hline Contribution of Manifold to $\Delta T$ & $(\%)$ & 52.5 & 64.5 \\
Average Maximum Insolation & $\left(\mathrm{W} / \mathrm{m}^{2}\right)$ & 1070 & 1050 \\
Average Total $\Delta T$ & $\left({ }^{\circ} \mathrm{C}\right)$ & 19.8 & 15.9 \\
Average Maximum Manifold Efficiency & $(\%)$ & 65.6 & 74.8 \\
\hline
\end{tabular}

Table 5. Summary of first and second law thermodynamic analysis.

\begin{tabular}{|c|c|c|c|}
\hline Test & $\begin{array}{l}\text { Maximum Insolation } \\
\left(\mathrm{W} / \mathrm{m}^{2}\right)\end{array}$ & $\begin{array}{l}\text { First Law Efficiency } \\
(\eta)(\%)\end{array}$ & $\begin{array}{l}\text { Second Law Efficiency } \\
(\varepsilon)(\%)\end{array}$ \\
\hline 1 & 1155 & 45.6 & 7.03 \\
\hline 2 & 1008 & 39.2 & 7.00 \\
\hline 3 & 1031 & 31.3 & 5.52 \\
\hline 4 & 838.2 & 32.0 & 4.85 \\
\hline 5 & 1248 & 60.1 & 2.57 \\
\hline 6 & 1022 & 62.9 & 5.57 \\
\hline 7 & 1246 & 52.5 & 3.07 \\
\hline 8 & 1018 & 49.5 & 3.00 \\
\hline 9 & 1007 & 23.0 & 2.56 \\
\hline 10 & 1000 & 26.6 & 2.83 \\
\hline 11 & 1029 & 61.5 & 6.61 \\
\hline 12 & 1002 & 25.4 & 5.06 \\
\hline 13 & 1248 & 64.5 & 0.61 \\
\hline 14 & 1002 & 31.4 & 4.40 \\
\hline Average & 1061 & 43.3 & 4.33 \\
\hline
\end{tabular}




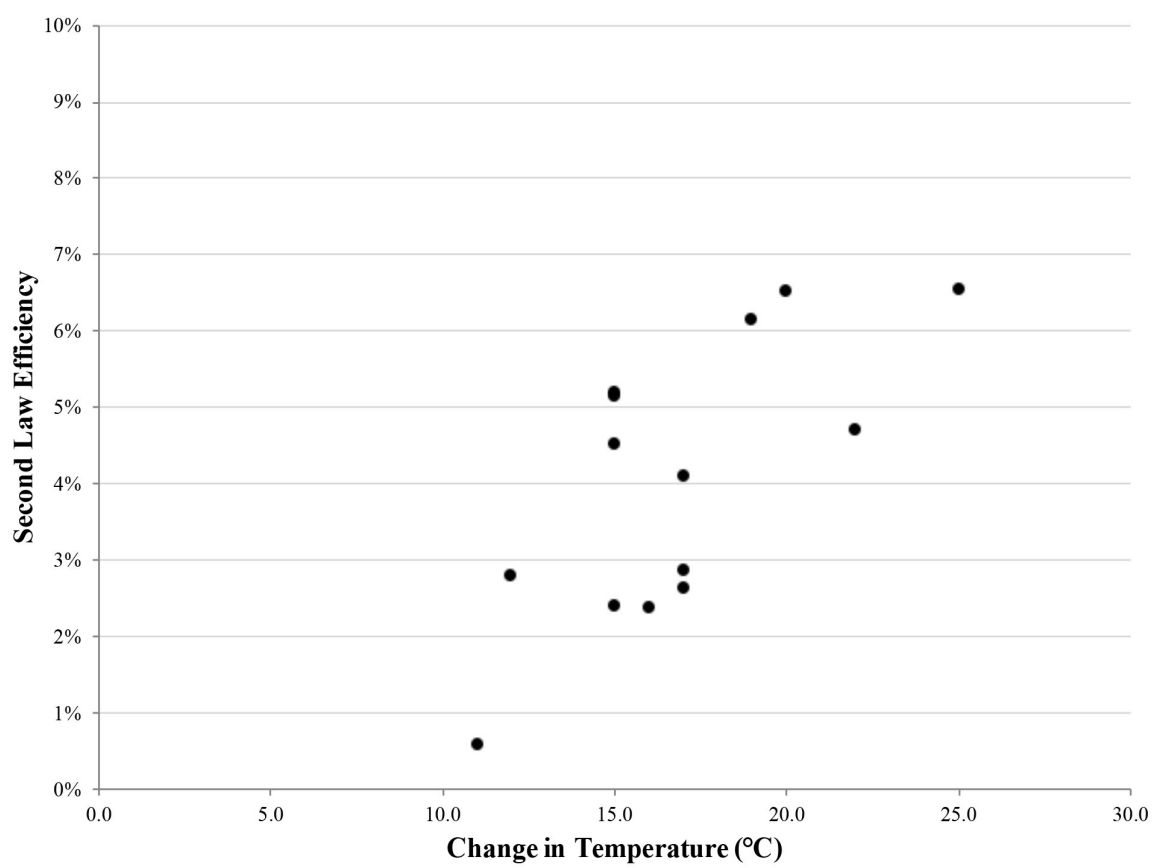

Figure 5. Effect of temperature change on second law efficiency $(\varepsilon)$.

testing to reach its peak performance. The flow remained at a fixed flow rate for all testing based on experimental work done by Zielinski, et al. [13]. Zielinski, et al. found that the collector was most efficient when its flow rate was at its lowest, around 0.001 liters/second. A low flow rate allows the working fluid to absorb the most energy as it passes through the system.

From a first law analysis standpoint, the next steps for this project will center on the optimization of the evacuated tube manifold. The manifold made a much smaller contribution to the overall temperature increase of the system than the prior system design. In the previous design of the system, the manifold was contributing close to $75 \%$ of the total temperature change, while it accounts for only $65 \%$ currently. Improving the insulation of the manifold may further increase its contribution to the system's change in temperature. During testing, a small amount of insulation added to the manifold increased the manifold's contribution by $12 \%$ (Table 3). Another change for future work is the orientation of the evacuated tubes. The orientation of the tubes should be changed by about $90^{\circ}$ so that they run north-south and more closely align with the prior position. This will increase their exposure to sunlight throughout the day and will allow the evacuated tubes to heat the water for a longer period of time.

The second law efficiency is dependent on the temperature difference between the inlet and exit of the collector, as can be seen in Figure 5. By increasing the amount of energy transferred to the working fluid, the system's second law efficiency will increase. As mentioned earlier, a study that altered the working fluid of a flat plate collector resulted in an increase in the second law efficiency [8]. This could be another avenue for improving this collector's efficiency. Another 
possible method for improvement would be to increase the insulation of the flat plate. During data collection, the surface of the plate facing away from the sun was warm to the touch, indicating that there was substantial heat being lost at that location. Increasing the insulation of the back of the plate would decrease heat loss and improve the amount of heat transferred to the working fluid, thus increasing the FPC's second law efficiency.

With the proposed changes, the system performance will increase. Increased performance produces higher temperature differentials across the system, bringing this solar collector one step closer to being a viable heat source for an Organic Rankine Cycle to produce power. Being able to produce power with solar energy in a climate that receives little sunlight broadens the applications of solar thermal energy systems, making small scale thermal collectors a viable power source in climates previously deemed unsuitable for solar energy systems.

\section{Conclusions}

Collector features that were variable from day to day of testing included plate angle, plate orientation, and insulation of the manifold. A south facing orientation of the flat plate was found to produce the highest temperature change across the flat plate at an angle of $27^{\circ}$ from the horizontal. Preliminary designs of insulation on the evacuated tube manifold showed promising results to increase the system performance.

Compared to the second law efficiency of a theoretical model of a flat plate collector, which yielded an efficiency of around 60\%, this system did not perform as well as theoretically possible. Other experimental analyses of flat plate collectors, however, yielded second law efficiencies ranging from $2 \%-25 \%$. The system at the upper end of that range added graphene nanoparticles to the water as the working fluid. The collectors with lower efficiencies used water without any added particles. The results from these analyses were similar to the second law efficiency of this collector, thus validating the results of this analysis.

Though the low efficiencies found in this analysis are not unusual among other flat plate collectors with water as the working fluid, they show that improvements should be made. Theoretically, flat plate second law efficiencies can reach $60 \%$. This leaves a great deal of room for improvement for this system's FPC. Recommended improvements focus on transferring the energy from the sun to the working fluid.

\section{Acknowledgements}

Thank you to the Katherine Bisbee II fund and the Oregon Alliance of Independent Colleges and Universities for the financial support of this project. Thanks to PGE for technical support and collaboration. Additional thanks to Jacob Amos for his help in building the new system and for his design input. Thank you also to Geoffrey Schwichtenberg and Chad Stillinger of George Fox University for their assistance with the data acquisition system. 


\section{Conflicts of Interest}

The authors declare no conflicts of interest regarding the publication of this paper.

\section{References}

[1] Arora, S., Chitkara, S., Udayakumar, R. and Ali, M. (2011) Thermal Analysis of Evacuated Solar Tube Collectors. Journal of Petroleum and Gas Engineering, 4, 74-82.

http://www.academicjournals.org/journal/JPGE/article-abstract/CF81F1C3607

[2] Commercial Solar Water Heaters|Evacuated Tube Solar Thermal Collectors. http://www.solarpanelsplus.com/evacuated-tube-collectors/

[3] Ayompe, L.M., Duffy, A., Mc Keever, M., Conlon, M. and McCormack, S.J. (2011) Comparative Field Performance Study of at Plate and Heat Pipe Evacuated Tube Collectors (ETCs) for Domestic Water Heating Systems in a Temperate Climate. Energy, 36, 3370-3378. https://doi.org/10.1016/j.energy.2011.03.034

[4] Chaichana, C., Kiatsiriroat, T. and Nuntaphan, A. (2010) Comparison of Conventional Flat-Plate Solar Collector and Solar Boosted Heat Pump Using Unglazed Collector for Hot Water Production in Small Slaughterhouse. Heat Transfer Engineering, 31, 419-429. https://doi.org/10.1080/01457630903375475

[5] Gang, P., Jing, L. and Jie, J. (2011) Design and Analysis of a Novel Low-Temperature Solar Thermal Electric System with Two-Stage Collectors and Heat Storage Units. Renewable Energy, 36, 2324-2333. https://doi.org/10.1016/j.renene.2011.02.008

[6] Yang, J.C., Jiang, Q.Y., Hou, J.X. and Luo, C.L. (2015) A Study on Thermal Performance of a Novel All-Glass Evacuated Tube Solar Collector Manifold Header with an Inserted Tube. International Journal of Photoenergy, 1-7.

[7] Manek, A. and Karunanidhi, S.G. (2016) Performance Evaluation of ETC Using Booster Mirrors. International Conference on Emerging Engineering Trends and Science (ICEETS-2016), 20-27.

[8] Said, Z., Alim, M.A. and Janajreh, I. (2015) Exergy Efficiency Analysis of a at Plate Solar Collector Using Graphene Based Nanouid. IOP Conference Series: Materials Science and Engineering, 92, 012015. https://doi.org/10.1088/1757-899X/92/1/012015

[9] Kalogirou, S.A., Karellas, S., Badescu, V. and Braimakis, K. (2016) Exergy Analysis on Solar Thermal Systems: A Better Understanding of Their Sustainability. Renewable Energy, 85, 1328-1333. https://doi.org/10.1016/j.renene.2015.05.037

[10] Jafarkazemi, F. and Ahmadifard, E. (2013) Energetic and Exergetic Evaluation of at Plate Solar Collectors. Renewable Energy, 56, 55-63.

https://doi.org/10.1016/j.renene.2012.10.031

[11] Ge, Z., Wang, H.T., Wang, H., Zhang, S.Y. and Guan, X. (2014) Exergy Analysis of Flat Plate Solar Collectors. Entropy, 16, 2549-2567. https://doi.org/10.3390/e16052549

[12] Hamed, M., Snoussi, A. and Brahim, A.B. (2014) Energy and Exergy Analysis of at Plate Solar Collectors in Transient Behaviors. 2014 5th International Renewable Energy Congress (IREC), IEEE, 1-6. https://doi.org/10.1109/IREC.2014.6826943

[13] Zielinski, A., Dillon, H., Baldwin, B., Forinash, C., Zada, K., Stillinger, C. and Dieter, K. (2016) Design and Performance of a Small Hybrid Solar Collector. ASME 2016 Power Conference, ASME, V001T10A001.

[14] Dieter, K., Stillinger, C., Dillon, H. and Zeilinski, A. (2016) Design and Build of an 
Electrical Generator and Load Control System for a Novel Small-Scale Hybrid Solar Thermal Collector. 2016 IEEE International Conference on Power System Technology, POWERCON 2016. https://doi.org/10.1109/POWERCON.2016.7754070

[15] Moran, M.J., Shapiro, H.N., Boettner, D.D. and Bailey, M.B. (2010) Fundamentals of Engineering Thermodynamics. John Wiley \& Sons. 